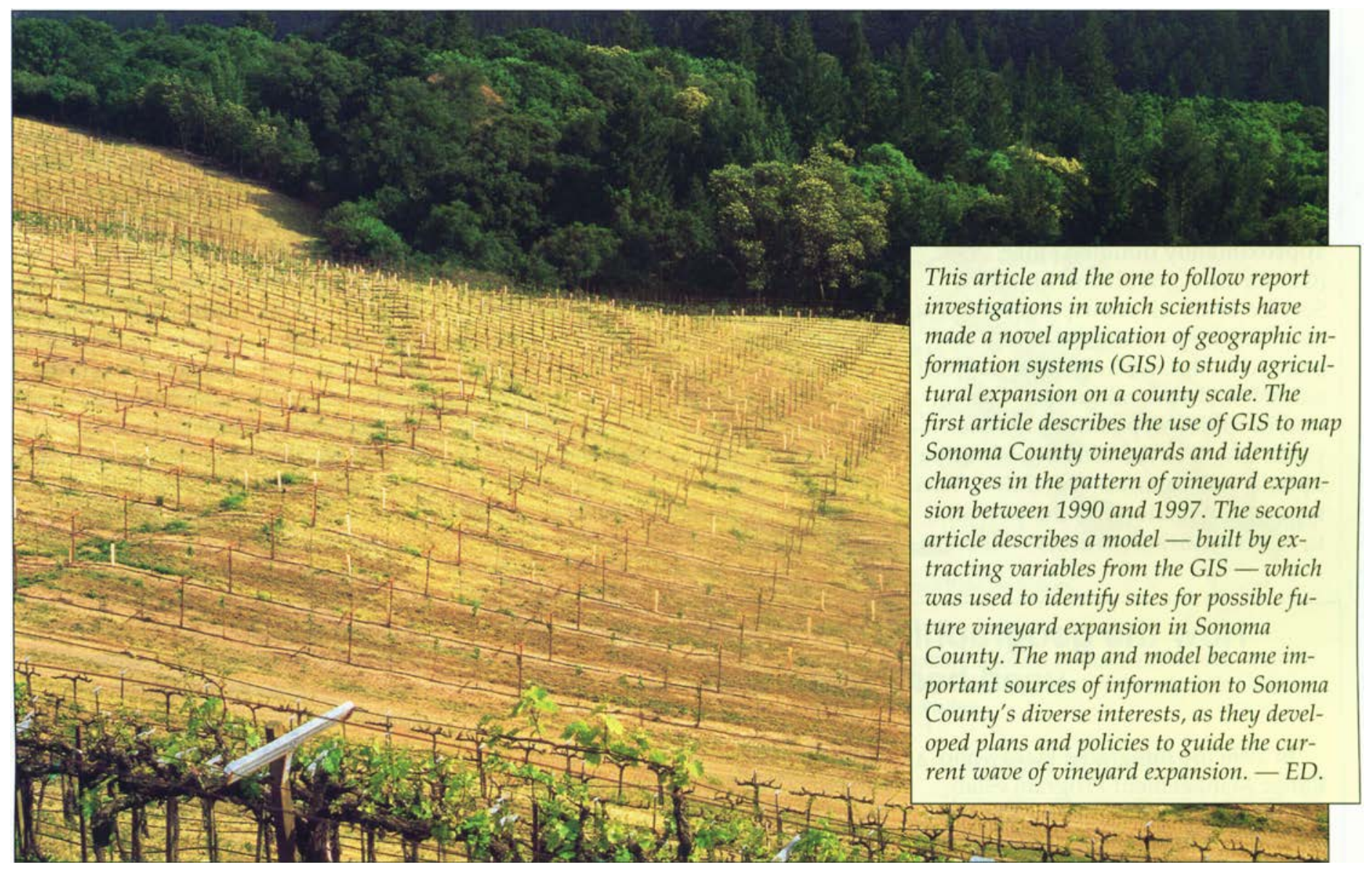

\title{
Mapping vineyard expansion provides information on agriculture and the environment
}

Adina M. Merenlender

Vineyards are expanding rapidly in California's coastal counties due to a booming wine market. This change in land use has led to public debate over natural habitat removal, overproduction of wine grapes, loss of agricultural diversity, and changing scenery. Using a geographic information system (GIS) to map and analyze vineyard expansion in Sonoma County, approximately 11,600 acres of new vineyards were identified from 1990 through 1997. The total acreage was calculated to be at least 48,000 acres in 1997, 20\% more than reported by county agricultural officials. Compared to vine- yards established before 1990, a higher percentage of vineyards planted between 1990 and 1997 were located on hillsides that supported oak woodlands. Oak woodlands support a majority of the region's biodiversity, provide ocosystem goods and services, and have aesthetic value. This research was designed to document the effects of recent vineyard expansion on Sonoma County's hardwood rangelands and to provide tools for informed discussion and decision-making by land-use planners, farmers, residents and environmentalists.
California wines are popular nationally and internationally, resulting in increased demand for highquality wine grapes, record-high wine bottle prices and increases in wine-grape planting. Over the past decade, shipments of wines that sell for $\$ 7$ a bottle and up have increased $157 \%$ (Press Democrat, Nov. 1, 1999). The California wine boom has been an economic blessing for many rural landowners, who can reap significant value by developing their land into vineyards. Money from the California wine industry also makes its way into many facets of the local economy by providing jobs and in- 
creasing tourism. Many local governments promote continued vineyard development and encourage regional wine-making to improve economic vitality.

Statewide, wine grape acreage has approximately doubled since 1990 (California Agricultural Statistics Service 1999). In some places this new vineyard acreage is being planted in upland areas that support oak woodlands and forests. Conversion of undeveloped land to vineyards involves the clearing of native upland and riparian vegetation. This type of conversion has the potential to affect natural resources - increas- ing hillside erosion, impacting endangered species or impeding wildlife migration. In addition, increased vineyard development may lead to overproduction of wine grapes, loss of local agricultural diversity and changing scenery.

As a first step toward addressing these issues, we used a geographic information system (GIS) to map and quantify the extent of hillside development and rates of natural habitat conversion (see sidebar, below).This effort demonstrated that published statistics on vineyard acreage are incomplete and could be improved by better mapping.

\section{How the geographic information system used here was built}

In 1996 the Integrated Hardwood Range Management Program established a geographic information systems (GIS) lab at the UC Hopland Research and Extension Center. GIS is a computer mapping and analysis tool that allows the integration of large amounts of spatial and nonspatial information. We used a GIS to integrate a map of Sonoma County's vineyards with other digital information.

The digital vineyard maps used for this project were originally compiled by the Sonoma County Grape Growers Association and put into digital format by Circuit Rider Productions, Inc. to produce high-quality maps for tourists and wine enthusiasts. Vineyards were identified in the major appellation areas of Sonoma County using 1990 aerial photographs, and more recent vineyard developments were mapped from information provided by the grape growers themselves through 1997 (fig. 1).

Other digital information that was used includes elevation, slope and aspect data derived from U.S. Geological Survey (USGS) Digital Elevation Models (DEM); roads and streams from the U.S. Census Bureau; farmland and urban areas from the Cali- fornia Department of Conservation Farmland Mapping and Monitoring Program; and vegetation from the California Department of Forestry and Fire Protection 1990 hardwoods layer. Additional base layers were also obtained from the Sonoma County Information Systems Department GIS Division.

This integrated GIS was intersected with maps showing the location of vineyards developed before and after 1990 with elevation and slope derived from the DEM. We also used this GIS to extract all of the variables used in the vineyard expansion model. Areas that met the designated regulatory levels in the Sonoma County Vineyard Erosion and Sediment Control Ordinance were identified by intersecting existing vineyards with the DEM and soils data. To assess the potential future impact of this ordinance, we also intersected the areas identified by the vineyard expansion model as being the most likely to be suitable for future vineyard expansion. This GIS holds promise of being a powerful analysis tool that we hope to improve and use to continue this research to examine land-use changes, quantify the environmental consequences and provide policy and planning analysis. - A.M.M.

\section{Sonoma County findings}

Sonoma County, which contains nine incorporated cities, is in the heart of the North Coast wine country and is one of the fastest growing counties in California. The U.S. Census Bureau reported a population increase of $282 \%$ from 1960 to 1995 (Census Bureau 1998). In addition to being one of California's premium wine-grape growing regions, Sonoma County's approximately 1 million acres include a substantial amount of hardwood rangeland (135,599 acres) and forests (561,468 acres) (ABAG 1996). Additionally, over $90 \%$ of the land is in private ownership.

A GIS was developed to analyze the amount and pattern of vineyard development in Sonoma County's major appellation areas, legally recognized wine-grape growing areas with specific geographic designations (fig. 1). We found that 11,663 acres of new vineyards were planted from June 1990 through June 1997, bringing acreage in grapes to at least 48,000 acres in 1997. This was $20 \%$ higher than the Sonoma County Agricultural Commissioner's estimate at the time. This larger figure was a surprise to most county residents, and was reported as front-page news with the headline, "New Sonoma County maps add 8,000 vineyard acres" (Press Democrat, June 1, 1998).

The GIS data layers used also included physiographic data such as slope, aspect and elevation (fig. 2). The integration of these data allowed us to demonstrate that upland areas are increasingly targeted for vineyard development. For example, in Sonoma County we estimate that $25 \%$ of the vineyards developed since 1990 were on slopes greater than 10 degrees $(18 \%$ slope) and $42 \%$ were above 328 feet (100 meters) in elevation (figs. 3 and 4). By comparison, less than $6 \%$ of the vineyards established prior to 1990 were on slopes greater than 10 degrees, and only $18 \%$ were above 328 feet. There are several reasons that are probably driving the move upslope: (1) flat land is developed; (2) when available, flat land is more expensive; and (3) the microclimate found on hillsides can result in higher quality wine grapes. 
The vineyards mapped in figure 1 were intersected with a 1990 digital vegetation map, allowing us to estimate the amount of undeveloped land converted to agriculture from 1990 through 1997. The 1990 vegetation map was derived from Thematic Mapper Satellite imagery provided by the California Department of Forestry and Fire Protection and was assumed to represent the vegetation cover types that existed in 1990 . The vegetation analysis showed that approximately 1,631 acres of dense hardwood forest (greater than 50\% tree cover), 278 acres of conifer, 367 acres of shrubland and 7,229 acres of oak grassland savarina were converted to vineyards between 1990 and 1997 in Sonoma County. It should be noted that these are slight underestimates, because vineyards outside the appellation areas in figure 1 had not been mapped and therefore could not be included in our analysis.

These GIS results demonstrate that Sonoma County has substantially more vineyard acreage than previously reported. Vineyards planted in the last 10 years typically occur at higher elevations and on steeper slopes than earlier plantings, resulting in the conversion of approximately 9,505 acres of undeveloped land.

\section{Problems in estimating acreage}

Based on our 1997 acreage estimates, the Sonoma County Agricultural Commissioner reported 51,500 acres of vineyards in the 1999 crop report (Sonoma County Agricultural Commissioner 1999). They added an estimated additional acreage of 3,500 to the 1997 figure of 48,000 , itself $20 \%$ greater than the estimate that year. This estimate comes closer to the true acreage for the county than the 43,316 acres reported by California Department of Food and Agriculture (1998). Likewise, the Santa Barbara Planning Department (1999) estimated harvested wine-grape acreage at more than 18,000 acres for 1998 , as compared to the Fruit and Nut Crop Report figure of 10,799 harvested acres (UC Fruit and Nut Research 2000).

Much of the difference between locally derived estimates of harvested acreage and published esti-

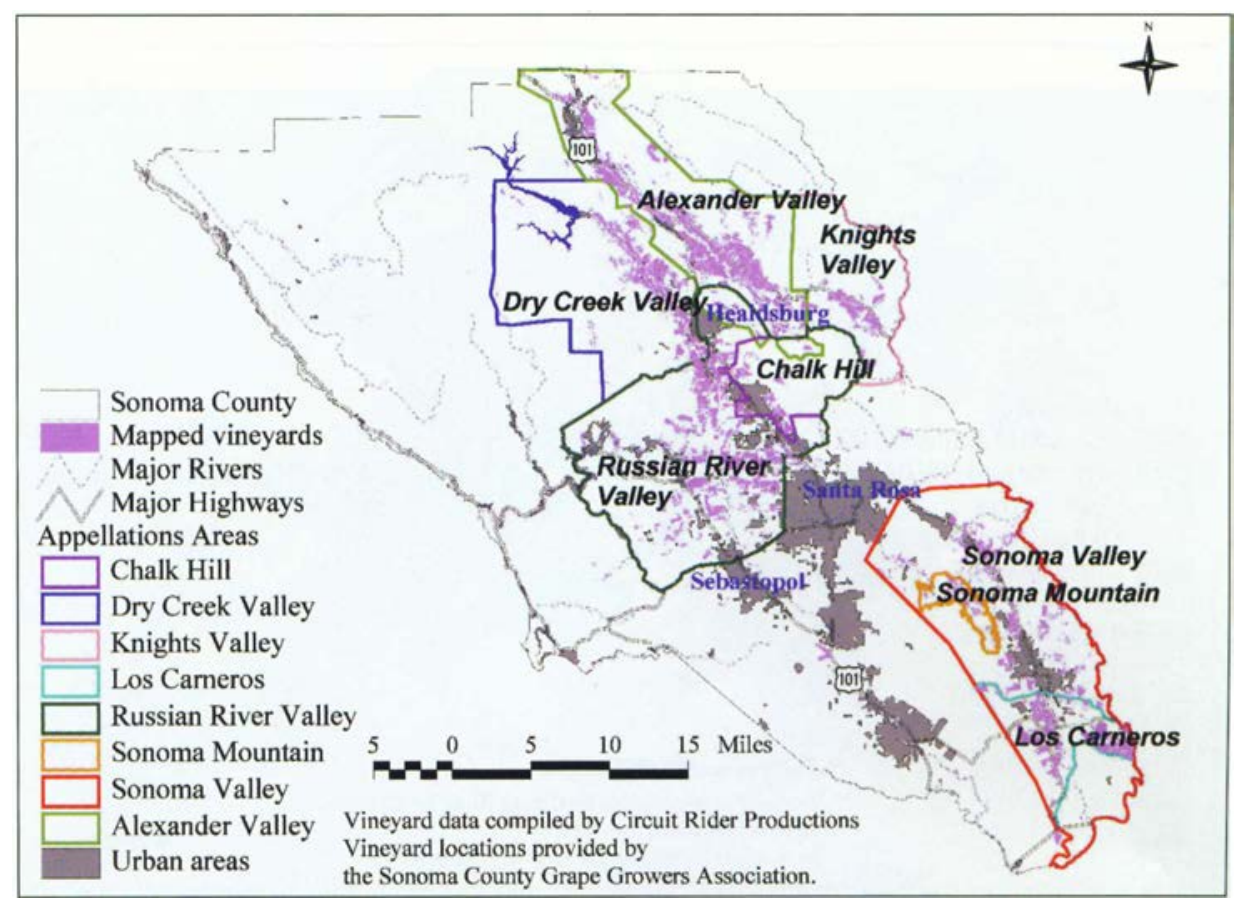

Fig. 1. Vineyards mapped within the major appellation areas of Sonoma County, including Alexander Valley, Russian River Valley, Chalk Hill, Dry Creek Valley, Knights Valley, Los Carneros, Sonoma Mountain and Sonoma Valley.

mates is due to the fact that growers may not report reliably or may not yet be accounted for in the system. The counties with the most rapid vineyard development rates are often the farthest behind in reporting, and consequently have less reliable data.

Other counties with expanding premium wine-grape acreage include San Luis Obispo with 14,988 acres reported (CDFA 1998) but actually closer to 23,000 planted acres (Deputy Agricultural Commissioner Robert Hopkins, personal communication, 1999), and Mendocino County with 14,264 acres reported (CDFA 1998) but closer to 17,000 actual acres (Agricultural Commissioner Dave Bengston, personal communication 1999). These discrepancies in wine-grape acreage figures indicate that a better system for mapping and monitoring agricultural change is needed. Aerial photography and other remote sensing technologies combined with GIS can be used to map and monitor agricultural areas and land use change as demonstrated for Sonoma County. This approach provides more accurate statistics on the amount of vineyard planted and could assist growers in determining whether current rates of production may exceed demand.

\section{Advantages of mapping}

Recently, environmental impacts and landscape change due to increased vineyard planting have been contentious issues in California. Federal courts have ruled that although landowners have the title to their land, they do not own the water, wildlife or other resources outright, and are responsible for managing these resources for the public trust (Araiza 1997). More information is needed to understand the consequences of vineyard expansion on a landscape scale as well as what site-specific vineyard development and management techniques can be used to minimize negative impacts to agriculture in general, neighboring landowners and the environment.

Advantages to agriculture. The wine-grape industry is highly susceptible to economic downturns due to lack of information on future demand and how many tons of wine grapes will be produced when vineyards planted today begin bearing fruit (on average vines come into full production after 6 years). Quantifying the amount of bearing and nonbearing acreage is important for farmers, wineries, financial lenders and land-use planners to determine grape production, reduce the chance of over supply, and assess the environmental impacts 


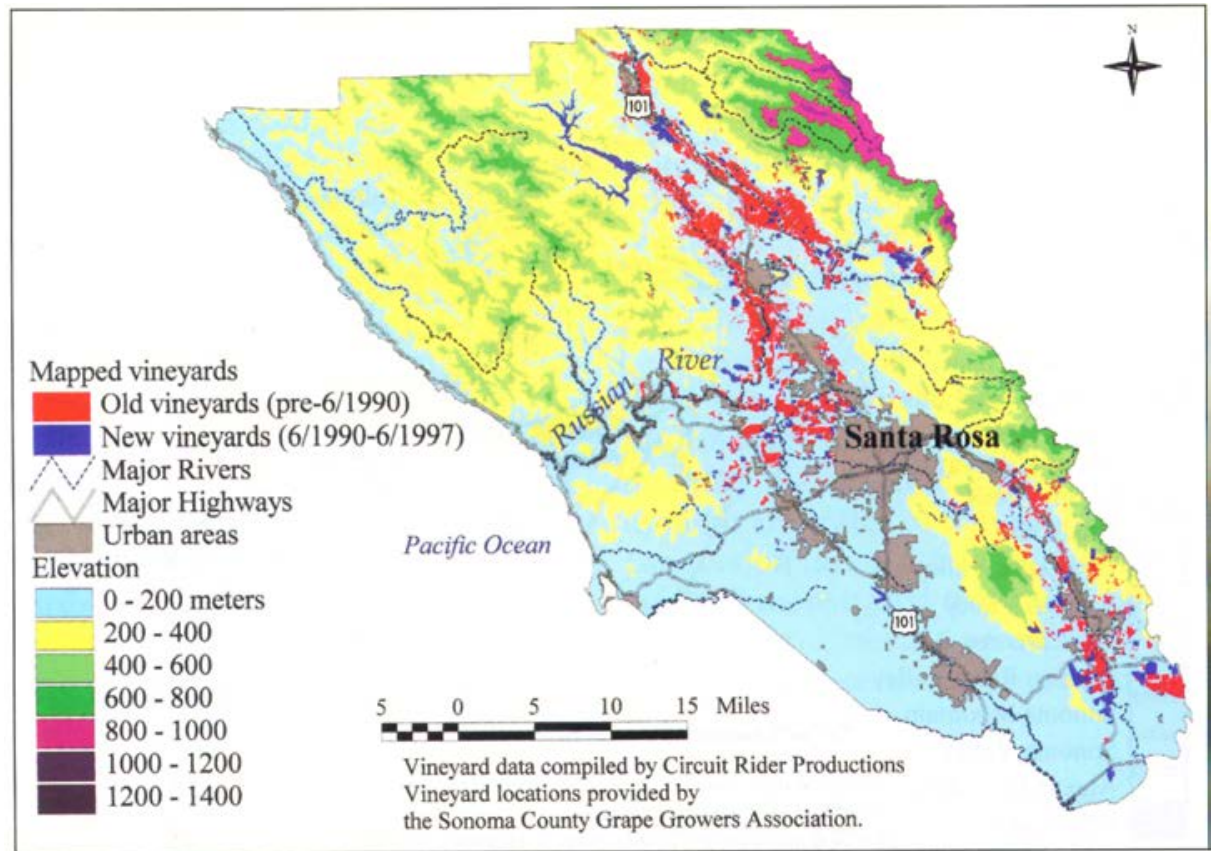

Fig. 2. Vineyards in Sonoma County with elevation classes. Vineyards mapped from 1990 aerlal photos are in red; those mapped by the grape growers as newly developed since 1990 are in blue.

of more vineyard development. Currently in Sonoma County, premium wine-grape growers can expect as high as $\$ 3,600$ net revenue per acre of vineyard land in full production (Press Democrat, Nov. 1, 1999). A downturn

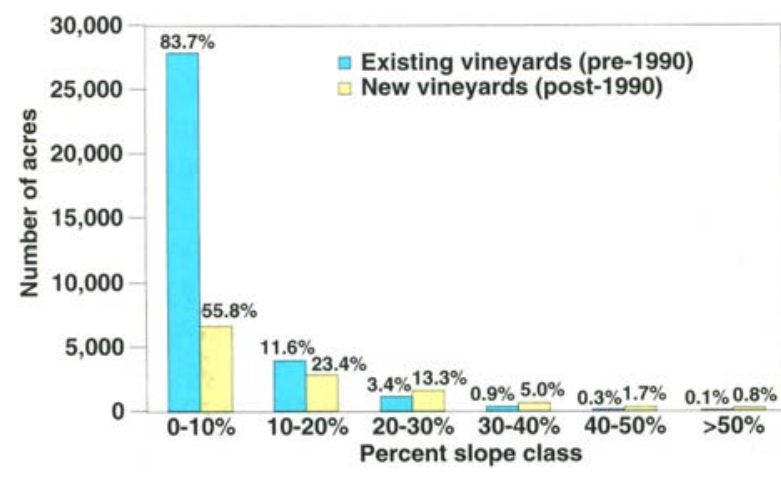

Fig. 3. Percent of total vineyard acreage before and after 1990 in slope classes.

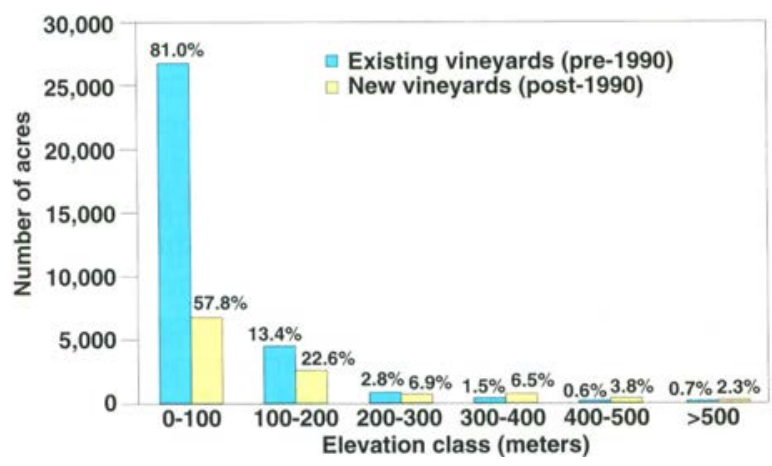

Fig. 4. Percent of total vineyard acreage before and after 1990 in elevation classes in wine-grape revenues could more quickly bankrupt heavily leveraged growers than growers without heavy debt loads. However, wine industry executives forecast a favorable market for at least another 3 years (Wine Industry Financial Symposium Survey 1999), in the belief that increasing numbers of people will appreciate good-quality wines (Stuller and Martin 1994) and be willing to pay more than $\$ 7$ per bottle. Economic optimism in the wine market prevails, despite the fact that wine-grape juice supply fluctuations in the past have led to large price drops and plowing up of vineyards, such as occurred in the Central Valley (Newsweek, Nov. 17, 1995).

In addition, the loss of diversity in agricultural systems can have consequences for California agriculture. For example, in Sonoma County, reductions in crop diversity are due both to market value decreases in orchard commodities such as apples, and to the increased value of wine grapes. Today there are no prune orchards and less than 5,000 acres of apples; formerly these were the leading farm commodities in the county. The average price of apples was $\$ 130$ /ton in 1999 , representing a $17 \%$ decline in price since 1998. Similarly, in Mendocino County pear and cherry orchards are being converted to wine grapes, and in Lake County both walnuts and pears are being replaced.

Moving toward a single agricultural crop across the North Coast is at odds with the principles of sustainable agriculture, and could lead to overreliance on a single industry. Proponents of sustainable agriculture promote increasing biodiversity in conventional farming systems to reduce insect pests and disease, and to reduce the use of insecticides, fungicides, herbicides and fertilizers (Bugg and Pickett 1998). In part this can be mitigated by planting a diverse suite of native cover crops in and around the vineyard.

Addressing residents' concerns. The expansion of vineyards, especially on hillsides, can result in changing scenery and deforestation, which can affect water resources. Some Central Coast residents have expressed dissatisfaction with the landscape after grazing land was converted to vineyards (Los Angeles Times, March 23, 1999). Some landowners have also claimed reduced flow from wells after vineyard development occurred on neighboring properties. (Water use, always a contentious issue in California, is usually settled in the courts.)

Habitat conversion. Oak woodlands - including both sparsely covered rangeland and denser oak forests - have been used primarily for livestock grazing and wood products but are increasingly targeted for vineyard development. These natural areas also support valuable game species such as deer and wild turkey. Properties containing oaks or adjacent to oak woodlands often have higher market value than similar properties without oaks (Standiford et al. 1987). Ecologically, oak woodlands are the most diverse ecosystems in California, providing critical habitat for approximately 2,000 plants, more than 100 birds, 60 mammals, 80 amphibians and reptiles, and 5,000 insect species (Pavlik et al. 1991).

This habitat has already undergone fragmentation due to suburban expan- 
sion, thinning for range improvement and firewood harvesting. In fact, over a million acres of California's oak woodlands have been converted since 1950 (Bolsinger 1988). To complicate matters, several oak species are not regenerating adequately to ensure long-term species survival (Bolsinger 1988). Vineyard expansion in coastal counties represents one of the latest threats to California's coastal oak woodlands.

Although many vineyards are planted in treeless areas, the conversion of woodlands and forests is extensive at some sites. The Santa Barbara County Planning Department reported that the amount of vineyard land has doubled to 20,000 acres since 1996, leading to the loss of more than 2,000 oak trees, a larger number than development of rural subdivisions was responsible for removing in the past 10 years. Even in less well known winegrape-growing areas such as San Luis Obispo County, an estimated 2,000 acres of rangeland are being converted to vineyards each year.

Converting oak woodlands to vineyards has discrete and identifiable effects, including the loss of vegetation cover, displacement of wildlife, soil disturbance and habitat fragmentation (Garrison 2000). The California Department of Fish and Game (CDFG) has listed 15 species that may be preferentially affected by vineyard development in coastal California (Garrison 2000). In addition to habitat loss and fragmentation, impacts on creeks and wetlands have been the focus of the regulatory agencies. The CDFG lists increased sedimentation, introduction of nonnative fish species as a result of increasing the number of reservoirs, and loss of wetland habitat as issues of concern for watersheds with vineyard development.

Although our research focus has been on oak woodlands, some North Coast vineyards have replaced coniferdominated forests that include redwood, Douglas fir and tan oak trees. However, very little data on this trend exists for Sonoma County because it has occurred so recently and is not reflected in the available maps and statistics on vineyard acreage.

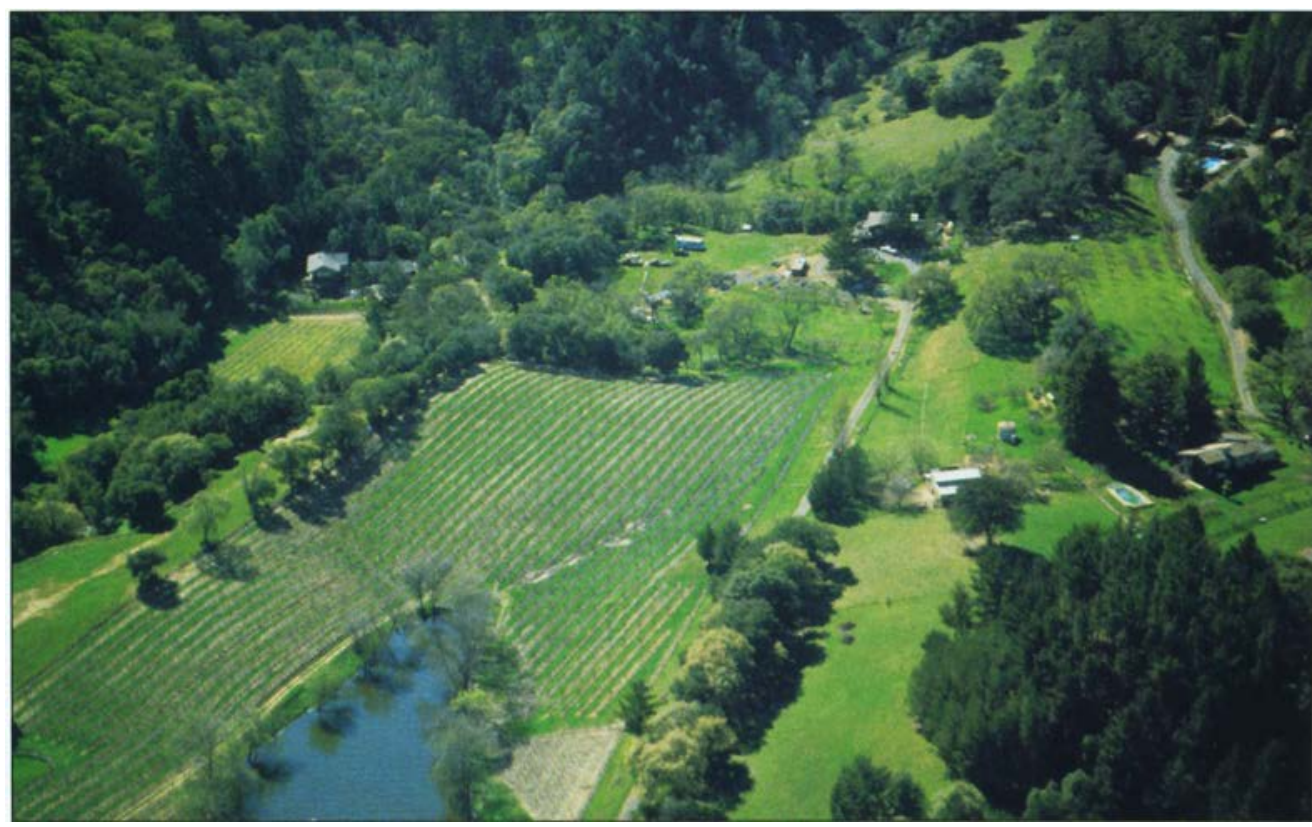

\section{Research needs}

Integrating spatial information on agricultural areas with other information about the landscape such as topography, hydrography and vegetation allows us to determine which watersheds may be disproportionately affected by vineyard development.

As we have demonstrated here, GIS is the best tool to do this, however, there are many areas in need of improvement. We would like to improve our mapping capabilities across a larger geographic area so that we can monitor the North Coast's rapidly changing landscape. An essential improvement would be to use remote sensing data for the mapping and monitoring of vineyard expansion across a larger geographic region and to assess changes in development patterns at regular time intervals.

Additional information on soils, climate, geology and water would also be of great benefit in analyzing vineyard development patterns. Higher resolution topographic information is becoming available and will improve our analysis capabilities as well. A combination of these improvements and further analysis of the relationships between land use and environmental conditions should prove valuable to those interested in agricultural land-use planning and environmental protection.
A A vineyard on the edge of an oak woodland in Sonoma County, where oaks are gradually being removed and replaced with grapevines.

A.M. Merenlender is Cooperative Extension Specialist, Integrated Hardwood Range Management Program, Department of Environmental Science, Policy and Management, UC Berkeley. UC Sustainable Agriculture Research and Extension Program funded this research. The Sonoma County Grape Growers Association, Circuit Riders Production, Inc., Glenn McGourty, Robert Hopkins, Dave Bengston and Abe Leider provided valu-

\section{Brochure explores vineyard} expansion issues

Vineyards in an Oak Landscape gives practical information on how to assess land-management decisions and balance agricultural production with natural-resource conservation. The brochure discusses the unique values of oak woodlands in California, the threats facing oak woodlands and how to care for existing oaks.

Along with information on oaks, the brochure outlines current information on disease, economic incentives and management practicies. To obtain a $\$ 4.50$ copy of publication number 21577, call DANR publications at (800) 994-8849. A.M.M. and Julia Crawford 
able data. Colin Brooks worked on the computer mapping and analysis. Charles Cooke, David Newburn, Emily Heaton, Kerry Heise and two anonymous reviewers provided valuable comments on the manuscript.

\section{References}

[ABAG] Association of Bay Area Governments. 1996. Existing Land Use in 1995: Data for San Francisco Bay Area Cities and Counties. Oakland, CA. 200 p.

Araiza WD. 1997. Democracy, distrust, and the public trust: Process-based constitutional theory, the public trust doctrine, and the search for a substantive environmental value. UCLA Law Review, 1997 Dec, v. 45 N2:385-452.

Bolsinger CL. 1988. The Hardwoods of California's Timberlands, Woodlands, and Savannas. US Forest Service PNW-RB148. $148 \mathrm{p}$.

Bugg RL, Pickett CH. 1998. Habitat management to enhance biological control: A concept and its applications. In: Pickett $\mathrm{CH}$, Bugg RL (eds.). Enhancing Biological Control: Habitat Management to Promote Natural Enemies of Agricultural Pests. Berkeley, CA: UC Press. p 1-23.

California Agricultural Statistics Service. 1999. May 25, 1999 California Grape Acreage Report. Calif. Department of Food and Agriculture.

[CDFA] California Department of Food and Agriculture. 1998. California Grape Acreage Annual Reports.

Census Bureau. 1998. Estimates of the Population of Counties by Age, Sex and Race/Hispanic Origin: 1990-1997. Washington DC.

Garrison, B. A. 2000. Draft Report: A Strategy for Conserving Oak Woodlands in Vineyard Landscapes. California Dept. of Fish and Game. 36 p.

Pavlik BM, Muick PC, Johnson S, Popper M. 1991. Oaks of California. Los Olivos, CA: Cachuma Press. $184 \mathrm{p}$.

Santa Barbara Planning Department. 1999. Santa Barbara Vineyard Acreage Report.

Sonoma County Agricultural Commissioner. 1999. Sonoma County Agricultural Crop Report 1999.

Standiford RB, Diamond N, Passof PC, LeBlanc J. 1987. Value of oaks in rural subdivisions. In: Proceedings of the Symposium on Multiple Use of California's Hardwood Resources. USDA Forest Service Gen. Tech. Report PSW-100. p 156-60.

Stuller J, Martin G. 1994. Through the Grape Vine: The Real Story Behind America's $\$ 8$ Billion Wine Industry. New York: HarperCollins. $365 p$.

UC Fruit \& Nut Research and Information Center. 2000. Fruit and Nut Crop Report. Department of Pomology, University of California.

Wine Industry Financial Symposium Survey. 1999. Universal Capital Corporation Vineyard Group, Napa, CA.

\title{
Modeling vineyard expansion, potential habitat fragmentation
}

\author{
Emily Heaton a Adina M. Merenlender
}

This is the first time that areas potentially suited to agriculture have been modeled using GIS for an entire county in California. Predictions made by the model are derived from the currently available data, which does not include such information as microclimate and soil profiles for specific sites. Scientists hope to add more information in the future. $-E d$.

We used a statistical modeling technique called logistic regression analysis, and a geographic information system (GIS), to map areas of possible future vineyard expansion in Sonoma County, based on data about vineyard development from 1990 through 1997. The goal of this research was to develop a model that would improve our understanding of vineyard expansion patterns at a landscape scale (for instance, including an entire county). The approach involved identifying landscape characteristics that were associated with vineyard development and mapping the areas with similar characteristics that were undeveloped in 1997. We used the results to map where habitat removal and fragmentation could result from vineyard expansion. This method, although still under development, is designed for county- or regional-scale analysis to assist land-use planners, natural resource protection agencies and land conservation programs in protecting valuable environmental resources while sustaining a vital agricultural economy.

While recognizing that the wine industry represents a significant portion of California's agricultural economy -
$\$ 1.3$ billion was paid for California wine grapes in 1999 (CASS 2000) - it is also important to preserve the ecological integrity of the natural resources upon which we all depend for services ranging from basic sustenance to aesthetic pleasure. Mapping and analyzing land use at the county scale can facilitate community efforts to balance economic growth and environmental protection. Land-use analysis and models can also aid planners in prioritizing undeveloped and agricultural land for possible protection through conservation easements and other methods.

Recently, vineyard development is expanding into rangelands, woodlands and forestlands (forests that include commercially harvested and regulated species such as Douglas fir), resulting in deforestation. We used results of our model to examine the potential for habitat loss and fragmentation. Model results can also be used to examine the possible effects of new regulations, such as those that restrict future vineyard development on steep slopes (see sidebar, p. 19).

\section{Modeling approach}

Our analyses have sought to identify areas that are most susceptible to future vineyard development in Sonoma County. Our primary assumption is that areas that share important characteristics with recently planted land are more likely to be developed into vineyards in the future. The results of our modeling efforts are strongly influenced by the development trends mapped for Sonoma County from June 1990 through June 1997. The model does not specify sites that will necessarily support the successful propagation of wine grapes, since some newer vineyards may have been planted in less productive places. Furthermore, site-specific characteristics, such as microclimate and some 